\title{
Permissive, Authoritarian, and Authoritative Parenting Style and Smartphone Addiction on University Students
}

\author{
Hifizah Nur \\ Faculty of Psychology \\ Universitas Mercu Buana \\ hifizah.nur@mercubuana.ac.id
}

\author{
Putri Setyaningrum \\ Faculty of Psychology \\ Universitas Mercu Buana \\ Putrisetyaningrum93@gmail.com
}

\author{
Annisa Novandita \\ Faculty of Psychology \\ Universitas Mercu Buana \\ novanditaannisa@yahoo.com
}

\begin{abstract}
This research was conducted to find the correlation between permissive, authoritative, authoritarian parenting styles with smartphone addiction. This study involved 225 students of one private university in Jakarta from various faculties (67 male and I58 female) selected based on a non-probability sampling method - convenience sampling. The measuring instruments used in this study were the Smartphone Addiction Scale (SAS) developed by Kwon et al. (20I3) and the Parenting Style scale developed by Baumrind (I97I), and the personal information form used to collect sample personal data. The quantitative analysis of the research was carried out using the Pearson product-moment test, Spearman correlation's test, descriptive test, t-test, and ANOVA test of difference. This study's results were there is a significant correlation of 0.320 between permissive parenting style and smartphone addiction, also there is a significant correlation of 0.300 between authoritarian parenting and smartphone addiction. Furthermore, there is no significant relationship between authoritative parenting and smartphone addiction.
\end{abstract}

Keywords: Smartphone Addiction, Permissive Parenting Style, Authoritarian Parenting Style, Authoritative Parenting Style.

Received 30 April 2021/Accepted I8 August 202I @Author all rights reserved

\section{Introduction}

The sophistication and convenience of smartphones today make people trapped in always using cellphones (Mashable, 2013). Researchers also report that the use of smartphones has a profound effect on changes in communication and daily lifestyle, as well as changes in social and emotional development patterns (Karaaslan \& Budak, 20I2; Chen \& Katz, 2009; Adriana \& James, 2005; Yilmatz et al., 20I5; Bianchi \& Philips, 2005; Cetin, 2015). More and more research findings prove that smartphones cause addiction, poor academic performance, lack of life satisfaction, and social stress (Bian \& Leung, 20I5; Bolle et al., 20I5; Hawi \& Samaha, 20I6; Lee \& Lee, 2016).

Addiction is defined as a repetitive pattern of habits that increases the risk of illness, personal and social problems, and experiencing feelings of being out of control (Laitakari et al. 1998, p. 224). 
According to Bilieux (20I2), Smartphone addiction is the loss of the ability to properly regulate smartphone use, resulting in negative consequences in daily life. Studies on smartphones show that improper use can lead to mental health symptoms and physical problems such as depression, preoccupation, and mood regulation under virtual space activities (Widyanto, Griffiths \& Brunsden, 20II; Young, 1998; Eklöf et al., 2007; Hagberg et al., 20II). These symptoms are similar to substance abuse and addiction, such as compulsive behavior, withdrawal, anticipation, and positive tolerance (Chang et al., 20I4; Cho et al., 20I6; Kim et al., 20I3). Kwan et al. (2013) state that the term smartphone addiction is the behavior of attachment or addiction to smartphones that allows social problems such as disturbances in daily life, positive anticipation, withdrawal, cyber-oriented relationships, excessive use, and increased tolerance smartphone use.

Several studies have shown an adverse effect of excessive smartphone use on the user's physical or psychological; for example, in the Sekarrini study (2020), excessive smartphone use produces mild anxiety and complaints in the arms, neck, and eyes. Then, in Kulachai's research (2018), excessive smartphone users will experience mood disorders, feel pain in the neck and fingers, experience disturbances in social relationships, especially with family, and experience decreased learning achievement because they are unable to concentrate while studying. Meanwhile, Kaya, Dastan, and Durar's (2020) research found a relationship between smartphone use and poor sleep quality and symptoms of depression in college students.

Previous studies have shown a strong relationship between parenting styles and adolescent deviant behavior, addiction, and other psychological problems. According to Barnes and Farrell (1992, p.773), parental support and monitoring is a strong predictor of adolescent problems, even after controlling for socioeconomic status, age, gender, race, family history of alcohol abuse, and family structure. Consistent with social learning theory, Barnes and Farrell found that parents who used coercive controls (screaming, yelling, slapping, and hitting) had adolescents who were more likely to exhibit behavioral deviations at school. Also, adolescents who report having high levels of home regulations or parental monitoring show the lowest rates of behavioral problems; drinking, drug abuse, deviance, or school delinquency (Julie A. Patock-Peckham \& Antonio A. Morgan-Lopez, 2006).

Good Excellent and positive parenting is closely related to the prevention of preventing 
delinquency, behavioral, psychological dysfunction, and addiction (Al-Bahrani, 20II; Betts et al., 20I3; Kehl et al., 2008). Parenting that severely limits children's freedom shown to lead to a higher likelihood of smartphone addiction (Lee \& Lee in Kwan Hoi Ching and Leung Man Tak, 2017). In addition, in Perris, Jacobsson, Lindstrom, von Knorring, and Perris (1980) description of the parenting style perceived by the subject, positive parenting styles are characterized by parental warmth (e.g., emotional support and acceptance). In contrast, negative parenting styles are characterized by parental rejection (e.g., parental hostility, harsh parenting, and punishment) and overprotection (e.g., strict regulation and monitoring, high levels of harassment of children) (Vera, Granero, \& Ezpeleta, 2012). Negative parenting styles can increase the degree of Smartphone dependence, while positive parenting styles can reduce Smartphone dependence (Bae in Lian et al., 2015). Baumrind, in 197I stated that there are three styles of parenting, namely authoritative, authoritarian, and permissive, which represent the styles used by parents in dealing with children. This style of parenting is based on high or low parenting intensity, demands for maturity, communication, and control of children's behavior (John R. Bury, 1989).

Ages 18-25 years are the transitional period between adolescents into young adults and are still influenced by their life experiences at previous ages (Santrock, 2017) so that apart from the influence of the environment outside the home, parenting style is an essential factor that affects individuals at this age.

In a survey conducted by the Indonesian Internet Service Providers Association (APJII), data was obtained that the most extensive internet users in Indonesia are aged between 19-34 years (49.52\%), and the devices used to access the internet are primarily smartphones or personal tablets (44.16\%). By looking at these data, it can be concluded that students with an age range of 18-2I years are part of Indonesia's most significant internet access.

In Kumagiz and Gündüz's (2016) study, it was found that the average value of smartphone addiction from students was based on the attitudes of their mothers. The smartphone addiction rates of those who considered their mothers to be authoritarian and protective were higher than those who considered their mother's attitudes as democratic. This result is significant because it emphasizes the importance of mother's attitude towards children's behavior. 
Nur, Misrawati, and Utami (2019) also found that students who perceive themselves as having permissive parenting have significantly higher average smartphone addiction than children with authoritarian and democratic parenting. Students who perceive themselves to have parents with authoritarian parenting have a higher average smartphone addiction than children with democratic parenting, although this difference is not significant.

As a preliminary study, the researcher conducted semi-structured interviews with 20 university students about their parenting styles and the level of smartphone addiction. This interview is designed based on the theory of parenting from Baumrind (Bury, 1989) and Smartphone Addiction from Kwon (2013). From the results of the interview, it was found that three of respondents whose parenting style tends to be authoritarian and has a high level of addiction to smartphones, and two respondents whose parenting is permissive with a relatively high level of smartphone addiction. Other respondents, on average, received authoritative parenting, and levels of smartphone addiction were between moderate and low.

Many studies on the relationship between parenting style and smartphone addiction have been carried out on children and adolescents. In these studies, it is often found that democratic or authoritative PS is associated with low SA levels (Bae, 20I5; Amalia and Hamid, 2020). In another study, it was also found that strict parental control or authoritarian PS was associated with higher levels of SA (Lee et al., 2018). Research on smartphone addiction that Kwan (20I5) conducted on college students did not directly link PS with SA, but first connected PS with self-regulation and selfesteem, then linked them with SA. Because university students in Indonesia commonly still depend on their parents, both emotionally and economically (Alfikaila, 2017), the parenting style applied to students relates to various aspects of their lives. This study aims to find a direct relationship between PS and SA level in university students.

From the description above, it can be concluded that there is a close relationship between parenting styles and smartphone addiction. This study wants to prove the existence of a relationship between these variables in the regular students of one private university in Jakarta. The questions to be answered in this study are:

- Is there a relationship between permissive, authoritarian, and authoritative parenting styles with smartphone addiction? 
- Are the parenting styles and smartphone addiction related to gender and GPA of the students?

\section{Method}

\section{Respondents}

This research uses quantitative methods with correlational analysis techniques and model testing. The population of the research results is the regular students at a private university in Jakarta. The population is based on consideration of age and occupational homogeneity. The sample selection is made by using a non-probability sampling technique - convenience sampling. Non-probability sampling is a sampling technique that is not randomized. It does not provide equal opportunities for every member of the population to be selected as a sample. Meanwhile, convenience sampling is a sampling technique based on the researcher's considerations for convenience to be done at any time (Malhotra, 2007; Istijanto, 2009). The sample that participated in this study was 225 students of one private university in Jakarta.

\section{Measurements}

Data collection was carried out through a survey using social media as WhatsApp groups and Facebook, using measuring instruments in the form of a questionnaire, namely the Smartphone Addiction Scale-Short version (Kwon, 20I3) and the Three Parenting Style Scale (Baumrind, 197I). Self-reports to collect socio-demographic data in age, majors, semester levels, and the last semester GPA were also carried out in data collection.

\section{Procedure}

This research was conducted in three stages, namely:

Preparation stage. The researchers conducted a preliminary study by conducting semi-structured interviews with 20 private university students based on research measurement tools, namely the smartphone addiction and parenting style scales. After the initial data is obtained, the researcher prepares a research proposal and revises the proposal.

Data collection stage. At this stage, the researchers distributed questionnaires to regular students of one private university by going through google form and distributed through student class groups. The deployment is carried out in two stages. The first stage, distributed to 97 students, 
then tested the validity, reliability, and item analysis. From the item analysis, it was obtained that Cronbach's alpha was 0.876 for smartphone addiction. Meanwhile, for the parenting style, the permissive style category obtained Cronbach's alpha of 0.724 ; for the authoritarian category, it was 0.860 , and for the authoritative, it was 0.910 . After the item analysis test, the questionnaire was distributed again in the second stage to student groups, and 128 respondents were selected who were willing to fill out the questionnaire. So, the overall sample who participated in this study was 225 people. Roscoe in Sugiyono (2019) states that if the research will be carried out a multivariate analysis (correlation or multiple regression), then the number of sample members is at least ten times the number of variables studied. So if this study using four variables (SAS, permissive parenting, authoritative parenting, and authoritarian parenting), the minimum sample size is 80 samples.

\section{Data analysis}

The data obtained in stage two was analyzed using several statistical testing techniques. It was the Pearson product-moment and Spearman's rho correlation test for testing the hypothesis, descriptive test, and the t-test and analysis of variance (ANOVA) for testing differences in each socio-demographic unit.

\section{Result}

In this section, we will describe the socio-demographic characteristics of the sample and then the correlation between three parenting styles and smartphone addiction. In the last section, the calculation results of SAS and Authoritarian Parenting Style difference results will be presented on Gender and GPA. 
Table I

Socio-demographic Characteristic of Sample

\begin{tabular}{|c|c|c|c|}
\hline \multicolumn{2}{|c|}{ Socio-demographic Characteristic of Sample } & \multirow{2}{*}{$\frac{N(225)}{67}$} & \multirow{2}{*}{$\begin{array}{l}\% \\
30\end{array}$} \\
\hline Gender & Male & & \\
\hline & Female & 158 & 70 \\
\hline \multirow[t]{6}{*}{ Faculty } & Psychology & 107 & 48 \\
\hline & Creative Art Design & 9 & 4 \\
\hline & Communication & 44 & 20 \\
\hline & Technique & 12 & 5 \\
\hline & Economic and Business & 41 & 18 \\
\hline & IT & 12 & 5 \\
\hline \multirow[t]{4}{*}{ GPA } & 1 & 4 & 1,7 \\
\hline & 2 & 9 & 4 \\
\hline & 3 & 104 & 46 \\
\hline & 4 & 108 & 48 \\
\hline \multirow[t]{5}{*}{ Year } & I & 79 & 35 \\
\hline & 2 & 55 & 24 \\
\hline & 3 & 39 & 17 \\
\hline & 4 & 47 & 21 \\
\hline & 5 or more & 5 & 2 \\
\hline
\end{tabular}

From the socio-demographic data above, it can be seen that $70 \%$ of the women who filled the questionnaire filled the questionnaire. Then the sample from the psychology faculty is the largest, at $48 \%$, followed by the communication science faculty at $20 \%$ and the business economics faculty at 18\%. Meanwhile, in terms of years of education, students from the first year were the most research samples, namely $35 \%$, followed by the second year at $24 \%$ and the fourth year at $21 \%$. For the GPA categorization, it can be seen that $94 \%$ of the sample have a GPA of 3 or more.

The results of the Kolmogorov-Smirnov test for SAS and the three types of parenting are as follows; for SAS 0.307, permissive PS 0.031 , authoritarian PS is 0.136 , and authoritative PS 0.000 with 2-tailed significance. From these results, it is clear that SAS and authoritarian parenting data 
are typically distributed because the significant level of both data is more than 0.05 , while permissive and authoritative parenting are not normally distributed.

From the questionnaire data, the results of the correlation test between the three parenting styles and smartphone addiction are shown below.

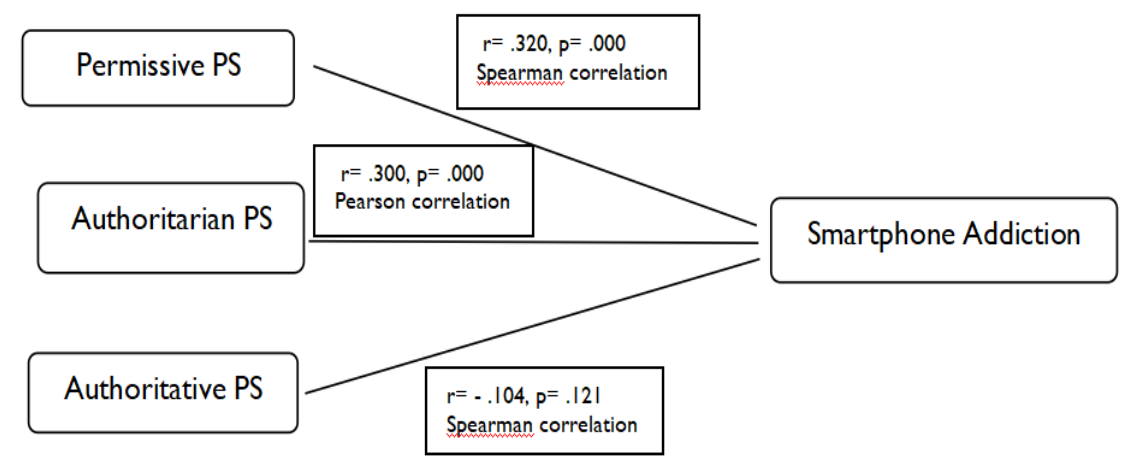

Figure I. Correlation between three parenting styles and smartphone addiction

The data shows there is a significant correlation of 0.320 between permissive parenting style and smartphone addiction. This data means, the higher the value of permissive parenting style, the greater the tendency of SAS to be. Meanwhile, the result of the correlation test between authoritarian parenting style and smartphone addiction shows a significant correlation of 0.300 . It means that the more authoritarian parenting style parents apply, the greater the tendency for SAS to be. The last data is the correlation test between authoritative parenting style and smartphone addiction. It shows a significant level of $0.121>0.05$, which means no significant correlation between smartphone addiction and authoritative parenting style. 
Table 2

SAS and Table Authoritarian Parenting Style t-test results on Gender

\begin{tabular}{lllcc}
\hline \multicolumn{1}{c}{ Dependent Variable } & Independent Variable & $\mathrm{t}$ & Significance \\
\cline { 1 - 2 } $\begin{array}{l}\text { Authoritarian Parenting } \\
\text { Style }\end{array}$ & male & 9.746 & 0,000 \\
\cline { 2 - 2 } Smartphone Addiction & female & & \\
\cline { 1 - 2 } & male & 9.746 & 0,000 \\
\hline
\end{tabular}

From the calculations above, we found the significance value is $0.000<0.05$, which means there is a difference between men and women in terms of SAS. There are also differences between men and women in terms of the authoritarian parenting of their parents.

Table 6

ANOVA Test Results from SAS and Authoritarian Parenting Style on GPA

\begin{tabular}{lcccc}
\hline Dependent Variable & $\begin{array}{c}\text { Independent Varibale } \\
\text { (GPA) }\end{array}$ & Mean & F & Significance \\
\cline { 2 - 3 } & 1 & & & \\
Authoritarian Parenting & 2 & 24,600 & & \multirow{2}{*}{0,074} \\
Style & 3 & 20,183 & & \\
& 4 & 19,759 & & \\
Smartphone Addiction & 1 & 64,50 & & \multirow{2}{*}{0,034} \\
& 2 & 69,00 & 2,930 & \\
\hline
\end{tabular}

From the table above, it is found that the ANOVA test results from the Authoritarian Parenting Style to the GPA are not significant because the significance level is $0.074>0.05$, which means that there is no difference in terms of GPA in authoritarian parenting. While the ANOVA test results of Smartphone Addiction on GPA, it appears that there is a difference with a significance level of 0.034 $<0.05$. The mean SAS for students with a GPA of I and 2 is higher than students with a GPA of 3 and 4. 


\section{Discussion}

This research was conducted on 225 private university students from various faculties in Jakarta.The aim was to analyze whether there is a relationship between three types of parenting and the level of smartphone addiction. If so, which type of parenting is positively and significantly related to smartphone addiction?

The results of the Spearman correlation calculation show that there is a positive and significant relationship between permissive parenting and smartphone addiction. The results means, the more permissive parenting style applied to respondents, the higher the level of their smartphone addiction. It confirms the results of preliminary research that show that parents' permissive parenting is related to the level of smartphone addiction in respondents. It is also in line with the research of Nur et al. (2019), which found that students who perceive themselves to have parents with permissive parenting have significantly higher average smartphone addiction than children with authoritarian and democratic parenting.

Parents who are permissive or indulgent are "untraditional and tolerant, lack mature behavior, allow children to self-regulate and avoid confrontation" (Baumrind, 1991, p. 62). It makes children more accessible in determining their activities, including in terms of smartphone use.

The Pearson correlation calculation result shows a positive and significant relationship between authoritarian parenting and smartphone addiction with a correlation level of 0.300 . The result means that the more authoritarian the parenting style is, the higher the level of someone's addiction to smartphones. These results confirm the preliminary research results, showing that students who consider their parents to be authoritarian have a higher rate of smartphone addiction. The results of this study are also in line with the research of Kumagiz and Gündüz (2016), which found that the level of smartphone addiction from students who considered their mothers to be authoritarian and protective was higher than those who considered their mother's attitudes as democratic.

According to Baumrind (199I), authoritarian parents are obedient and status-oriented and expect their orders to be obeyed without explanation. A study by Lian et al. (2016) stated that excessive protection, which implies strict rules and monitoring and a high level of coercion by parents on children, can increase the risk of children seeking friendship through excessive use of smartphones. 
The results of the Spearman correlation calculation show that there is no significant relationship between authoritative parenting and the level of smartphone addiction. These results broke the prediction at the beginning of the study of a negative and significant association between authoritative parenting and levels of smartphone addiction. Therefore, further research is needed to ensure the relationship between these two variables.

The results of the t-test for smartphone addiction show that there are differences between men and women. The result is different from the results of Kumagiz and Gündüz's (2016) study, which found no significant difference between men and women in terms of their smartphone addiction level. Meanwhile, Nur et al. (2019) research also shows a significant difference in terms of SAS, with the mean score of men being higher than women, which is confirmed by the results of the current study. Then the t-test results from authoritarian parenting also show differences in the level of parenting between men and women.

The ANOVA test of authoritarian parenting on student academic achievement does not show any differences, so it can be concluded that authoritarian parenting does not affect student academic rankings. Meanwhile, the ANOVA test for the level of smartphone addiction on academic achievement showed a significant difference, with the mean SAS for students with GPA I and 2 being higher than students with GPA 3 and 4. The test indicates a more significant smartphone level addiction in students with GPA I and 2 of the students with a GPA of 3 and above. It reinforces the claim that smartphones cause addiction, poor academic performance, lack of life satisfaction, and social pressure (Bian \& Leung, 2015; Bolle et al., 2015; Hawi \& Samaha, 2016; Lee \& Lee, 2016). One aspect of smartphone addiction is daily life disturbance or distraction of everyday life. Disturbances in daily life include not doing the planned work, difficulty concentrating in class, suffering from lightheadedness, blurred vision, pain in the wrist or back of the neck, and sleep disturbances. In addition, smartphone users also have difficulty concentrating on activities or work because they keep thinking about their smartphones.

\section{Conclusion}

This research was conducted on 225 students at private university from various faculties to see whether there is a relationship between the three types of parenting and the level of smartphone addiction. In these results, the researcher found a positive and significant relationship between 
permissive parenting and smartphone addiction with a correlation level of 0.320 . Also, there is a positive and significant relationship between authoritarian parenting with a correlation level of 0.300 . The last, there is no significant relationship between authoritative parenting and the level of smartphone addiction.

Meanwhile, the results of the t-test for smartphone addiction show that there are differences between men and women; also, t-test results from authoritarian parenting show that there are differences in the level of parenting between men and women.

The ANOVA test of authoritarian parenting on student academic achievement does not show any differences, so it can be concluded that authoritarian parenting does not affect student academic rankings. However, the ANOVA test for the level of smartphone addiction on academic achievement showed a significant difference, with the mean SAS for students with GPA I and 2 being higher than students with GPA 3 and 4. The test indicates a more significant smartphone level addiction in students with GPA I and 2 of the students with a GPA of 3 and above.

\section{References}

Alfikalia (20I8). Keterlibatan orang tua dalam pendidikan mahasiswa di perguruan tinggi. INQUIRY Jurnal Ilmiah Psikologi, 8(I), 42-54.

Amalia, R. F., \& Hamid, A. Y. S. (2020). Adiksi smartphone, kesehatan mental anak, dan peranan pola asuh. Jurnal Ilmu Keperawatan Jiwa, 3(2), 22I-240.

APJII (20I8, I0 I2). Infografis penetrasi \& perilaku pengguna internet Indonesia 2017. Retrieved from: https://web.kominfo.go.id:https://web.kominfo.go.id: https://web.kominfo.go.id/sites/default/files/Laporan\%20Survei\%20APJII_20I7_vI.3.pdf

Bae, S. M. (2015). The relationships between perceived parenting style, learning motivation, friendship satisfaction, and the addictive use of smartphones with elementary school students of South Korea using multivariate latent growth modeling. School Psychology International, 7, I-19.

Buri, J. R. (1989). An instrument for the measurement of parental authority prototypes. Paper presented at the Annual Meeting of the Midwestern Psychological Association (6 Ist, 666Chicago, IL, May 4-6).

Gaumer Erickson, A.S., \& Noonan P.M. (2018). Self-regulation formative questionnaire. http://www.researchcollaboration.org/uploads/Self-RegulationQuestionnairelnfo.pdf 
Gokçearslan, S., Filiz, K. M., Haslaman, T.,\& Çevik, Y. D. (20।6). Modelling smartphone addiction: The role of smartphone usage, self regulation, general self-efficacy, and cyberloafing in university students. Journal Computers in Human Behavior, 63, 639-649. www.elsevier.com/locate/comphumbeh

Julie A. P.P., \& Antonio A. M. L. (2006). College drinking behaviors: Mediational links between parenting styles, impulse control and alcohol-related outcomes. Journal Psychology of Addictive Behaviors, 20(2), I17-125.

Kaya, F., Dastan, N. B., \& Durar, E. (2020). Smartphone usage, sleep quality and depression in university students. International Journal of Social Psychiatry, 4, I-8.

Kumagiz, H., \& Gunduz, Y. (20I6). Relationship between psychological well-being and smartphone addiction of university students. International Journal of Higher Education.

www.sciedupress.com/ijhe

Ching, K. H., \& Tak, L. M. (20I7). The structural model in parenting style, attachment style, self-regulation and self-esteem for smartphone addiction. IAFOR Journal of Psychology \& the Behavioral Sciences, 3(I), 167-172.

Kwan, H. C. \& Leung, M. T. (20I5). The path model of parenting style, attachment style, self-regulation and Smartphone addiction. Applied Psychology - Proceedings Of The 2015 Asian Congress (Acap 20I5)

Kwon, M., Lee, J., Won, M., Park , J., Min, J., Han, C., \& ...et.all. (20I8). Development and validation of a smartphone addiction scale (SAS). Plos One.

Lee, E. J., \& Ogbolu, Y. (20I8). Does parental control work with smartphone addiction. Journal of Addictions Nursing,29(2), 128-138.

Nur, H., Misrawati, D., Utami, S. (2019). What is the influence of smartphone addiction on student's psychological well-being? Southeast Asia Psychology Journal, 9, I 22-I 37.

Ribeiro, L.L. (2009). Construction and validation of a four parenting style scale. A Thesis. Presented to The Faculty of Psychology, Humboldt State University.

Sekarrini, L. (2020). The impact of smartphone usage in adolescents I5-24 years old in JABODETABEK region. The Indonesian Journal of Public Health, I5(I) II3- I 2 I.

Turner, E. A., Chandler, M., \& Heffer, R. W. (2009). The influence of parenting styles, achievement motivation, and self-efficacy on academic performance in college students. Journal of College Student Development, 50(3), 337-346.

Young, K.S., \& Abreu, C. N. (2017). Kecanduan internet: Panduan konseling dan petunjuk evaluasi dan penanganan. Pustaka Pelajar: Yogyakarta. 